\title{
Indian Derivatives Market: A Study of Impact on Volatility and Investor Perception
}

\author{
Divya Verma Gakhar
}

\begin{abstract}
Derivatives Market has an important role to play in the economic development of a country. The objective of the study is to examine the impact of financial derivatives (futures and options) on the underlying market volatility. The paper also analyses derivatives awareness level of Indian investor and perception of investor about future of derivatives market in India.

Data has been collected for a period of 18 years from January 1, 1997 to February 5, 2015. The questionnaire was distributed to 1000 respondents but 522 filled questionnaires were received and have been analyzed in this study.

The final AR (1)-GARCH $(1,1)$ model show that overall volatility has reduced in the spot market after the introduction of derivatives. The results of Structural Equation Modelling reveals perception of investors about future of derivatives market in India includes having an investor grievance redressal mechanism which is approachable under trading hours, steps to be taken by regulators to increase investments, conducting investor training and awareness programmes, global integration will happen, derivatives market will affect growth of the economy and consolidation of exchanges is required.
\end{abstract}

Index Terms-Volatility, derivatives, GARCH, perception, derivatives awareness level, NIFTY.

\section{INTRODUCTION}

Derivatives Market has an important role to play in the economic development of a country. In India derivatives were introduced as it offers various benefits.

Two hypotheses exist on the impact of derivatives on spot market volatility. Proponents of 'destabilizing forces' hypothesis argue that derivatives trading increases stock market volatility because of high degree of leverage. So, volatility will increase after introduction of derivatives. Proponents of 'market completion' hypothesis argue that derivatives trading helps in price discovery, improve the overall market depth, enhance market efficiency, augment market liquidity, reduce asymmetric information and thereby reduce volatility of the cash market (Kumar et al, 1995; Antoniou et al., 1998) [1]. This paper is an attempt to identify this relationship.

Apart from this, the paper also identifies derivatives awareness level of Indian investor and their perception about future of derivatives in India. For this purpose a structured questionnaire was designed and responses were collected from 522 respondents.

The rest of the paper covers the following sections: review

Manuscript received February 29, 2016; revised April 30, 2016.

Divya Verma Gakhar is with University School of Management Studies Institution - Guru Gobind Singh Indraprastha University, New Delhi, India (e-mail: divya.ipu@gmail.com). of literature is explained in section two, section three explains the methodology of the study, section four presents the empirical results and finally, conclusions are presented in section five.

\section{REVIEW OF RELATED RESEARCH}

Various studies have been undertaken on studying the impact on volatility after introduction of derivatives. Kalantzis, G.F. and Milonas, N.T. (2013), Gahlot, Ruchika and Dutta, Saroj Kumar (2012), Sahu, D. (2012), Singla, R. (2012), Kaur, Gurpreet (2011), Sakhtivel, P. and Kamaiah, B. (2011), Singh, G. and Kansal, S. (2010), Saravanan, G. and Malabika, Deo (2010), Pati, P.C. and Rajib, P. (2010), Gupta, K. and Singh, B. (2009), found that volatility has reduced after introduction of futures trading [2]-[11]. Kabir and Ikram (2012) could find significant impact of futures trading on stock market volatility [12]. Rajoub and Azzam (2012) found high volatility and negative correlation with returns at the time of market crisis [13]. Girish, G.P. (2012), Gahlot, R., Datta,K. and Kapil, S. (2010), Manier, M. (2009), Mallikarjunappa, T. and Afsal, E.M. (2008), Debasish, S.S. (2008), Yu, Shang-Wu. (2001) did not find significant change in the volatility [14]-[18]. Butterworth, D. (1998) found an increase in market efficiency, affected by futures trading [19]. Otswal, Priyanka (2011) reported that as expiration day come closest, the volatility of the market increased [20]. Gaurishankar S. Hiremath, (2009), Yu, Shang-Wu. (2001), Gulen, M and Stewart, M (2000), Figlewski (1981) and Chatrath et al.(1995), Harris (1989), Ross (1989) found that volatility has increased [21]-[26]. Jegadeesh and Subrahmanyam (1993) found that average spread has increased after introduction of futures trading [27]. Al-Zoubi and Kh.Al-Zu'bi (2007) found positive risk-return relationship [28]. Ray, K. and Panda, A.K. (2011) found stronger volatility structure in post derivatives period [29]. Rao, Ananth (2008) indicates that volatility persistence and spillover exist in all these markets [30]. Siopis and Lyroudi (2007) found a negative impact of introduction of futures trading on underlying volatility [31]. Katsikas (2007) found negative relationship between volatility and returns [32]. Saatcioglu, K. and Starks, L. (1998) found no relationship between weekly prices and volume and positive relationship between monthly prices and volume [33]. Xie S. and Huang J. (2014) did not found any decrease in the volatility, no leverage effect and a decrease in sensitivity to new information after introducing the CSI 300 index futures [34]. Stulec, I., et al., (2013) found that investors perceived derivatives as a risky instrument and only high class can invest in this [35]. Brahmabhatt, Raghu Kumari, P.S, 
Malekar, Shamira, (2012) found that the awareness of investment knowledge, investment opportunities is very high in Mumbai [36]. Thomas, T. C. and Rajendran, G., (2012) assessed the impact of the use of BB\&K Five-way Model on investment behavior of individual investors [37]. Kumar, R.T.Nirmal Balaji.K And Prabu.K (2011) studied on trader`s perception on options trading with the products traded in the national stock exchange [38]. No significant relationship is found between the experience and risk taking capacity of the trader. Martin,A., et al. (2009) found that the possibility of development of financial derivatives market in Peru is less due to less market regulations and less training [39]. Guay W \& Kothari, S. P. (2003) investigated that how much non-financial firms use derivatives as a hedging tool [40]. ANZ Banking Group, (2003) examined adult financial literacy in Australia by ANZ telephonic survey on 3548 adults [41]. They found low financial literacy level among the Australian respondents.

\section{Methodology OF THE StUdy}

The objective of the study is to examine the impact of financial derivatives (futures and options) on the underlying market volatility. The paper also analyses the investor behavior and perception of investor about future of derivatives market in India. The investor behavior has been studied in terms of their investment pattern and derivatives awareness level.

TABLE I: DESCRIPTIVE STATISTICS OF SAMPLE PERIOD (01-01-1997 TO 05-02-2015)

\begin{tabular}{|l|c|c|c|c|} 
& Nifty & Nifty Junior & S\&P 500 Index & Nifty Futures \\
\hline Mean Returns & 0.0435 & 0.0557 & 0.0238 & 0.0432 \\
\hline Maximum & 16.3343 & 13.8254 & 10.9572 & 16.1947 \\
\hline Minimum & -15.9810 & -19.4901 & -9.4695 & -17.5194 \\
\hline Std. Dev. & 1.6844 & 1.8911 & 1.2901 & 1.7123 \\
\hline Skewness & -0.4123 & -0.6968 & -0.1778 & -0.8867 \\
\hline Kurtosis & 12.0504 & 9.8224 & 11.0783 & 16.3048 \\
\hline Jarque-Bera & 5024.4800 & 8820.7240 & 11894.7800 & 24779.9000 \\
\hline Probability & 0.0000 & 0.0000 & 0.0000 & 0.0000 \\
\hline & & & & \\
\hline Sum & 190.0424 & 243.2152 & 103.7412 & 142.6426 \\
\hline Sum Sq. Dev. & 12384.8600 & 15610.5300 & 7264.4680 & 9675.5480 \\
\hline Observations & 4366 & 4366 & 4366 & 3301 \\
\hline
\end{tabular}

TABLE II: GARCH $(1,1)$ ESTIMATES FOR PRE-DERIVATIVES PERIOD

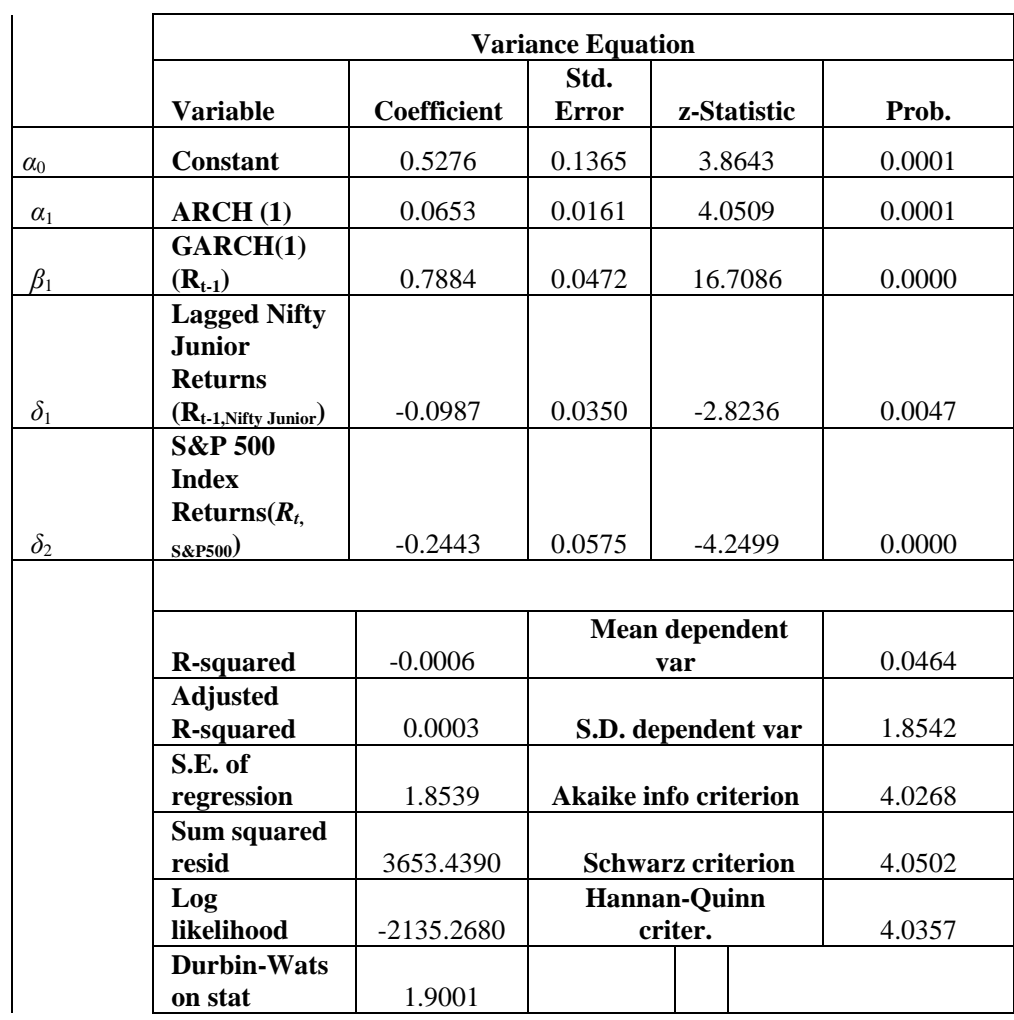


TABLE III: GARCH $(1,1)$ ESTIMATES FOR POST DERIVATIVES PERIOD

\begin{tabular}{|c|c|c|c|c|}
\hline & Variable & Std. Error & z-Statistic & Prob. \\
\hline & Constant & 0.0253 & 5.1804 & 0.0000 \\
\hline & $\mathbf{A R}(\mathbf{1})$ & 0.0185 & 6.2666 & 0.0000 \\
\hline & \multicolumn{4}{|c|}{ Variance Equation } \\
\hline$\alpha_{0}$ & Constant & 0.0665 & 15.8867 & 0.0000 \\
\hline$\alpha_{1}$ & ARCH (1) & 0.0155 & 14.8850 & 0.0000 \\
\hline$\beta_{1}$ & $\begin{array}{l}\text { GARCH(1) } \\
\left(\mathbf{R}_{t-1}\right)\end{array}$ & 0.0188 & 31.1128 & 0.0000 \\
\hline$\delta_{1}$ & $\begin{array}{l}\text { Lagged Nifty } \\
\text { Junior } \\
\text { Returns } \\
\left.\text { ( } \mathbf{R}_{t-2, \text { Nifty Junior }}\right) \\
\end{array}$ & 0.0126 & -8.0669 & 0.0000 \\
\hline$\delta_{2}$ & $\begin{array}{l}\text { Lagged S\&P } \\
\text { 500 Index } \\
\text { Returns }\left(\mathbf{R}_{\mathrm{t}-2,}\right. \\
\text { S\&P500) } \\
\end{array}$ & 0.0091 & -32.1248 & 0.0000 \\
\hline$\gamma$ & $\begin{array}{l}\text { Futures_Du } \\
\text { mmy }\left(D_{\mathrm{f}}\right)\end{array}$ & 0.0039 & -13.2528 & 0.0000 \\
\hline \multirow[t]{9}{*}{$\lambda$} & $\begin{array}{l}\text { Options } \\
\text { Dummy }\left(D_{0}\right)\end{array}$ & 0.0498 & -10.9877 & 0.0000 \\
\hline & R-squared & Mean dependent var & \multicolumn{2}{|l|}{0.0438} \\
\hline & Adjusted R-sq & S.D. dependent var & \multicolumn{2}{|l|}{1.6848} \\
\hline & S.E. of regress & Akaike info criterion & \multicolumn{2}{|l|}{3.6771} \\
\hline & Sum squared I & Schwarz criterion & \multicolumn{2}{|l|}{3.6902} \\
\hline & Log likelihood & Hannan-Quinn criter. & \multicolumn{2}{|l|}{3.6817} \\
\hline & Durbin-Watso & & & \\
\hline & Inverted AR R & & & \\
\hline & \multicolumn{4}{|c|}{$\begin{array}{l}\text { Method: ML - ARCH (Marquardt) - Normal distribution } \\
\text { Presample variance: backcast (parameter }=0.7 \text { ) } \\
\text { Convergence achieved after } 8 \text { iterations }\end{array}$} \\
\hline
\end{tabular}

Data has been collected for a period of 18 years from January 1, 1997 to February 5, 2015. Data has been collected for various indexes like CNX S\&P Nifty index daily closing prices (from January 1, 1997 to February 5, 2015), Nifty Junior Index (from January 1, 1997 to February 5, 2015), Index Futures near month contracts daily closing prices from (June 12, 2001 to February 5, 2015) and S\&P 500 Index (from January 1, 1997 to February 5, 2015). The data was

collected from NSE website. The closing price data was converted to daily compound returns by taking the first log difference.

The questionnaire was distributed to 1000 respondents but 522 filled questionnaires were received and have been analyzed in this study. The questionnaire was subjected to reliability and expert validity.

\section{RESULTS AND DISCUSSION}

After fifteen years of introduction of derivatives in Indian capital markets, it's time to relook on the impact of derivatives on the underlying market.

\section{A. Impact on Volatility}

The results of the analysis as shown in Table I depicts that mean returns is positive for all series for the total period (01-01-1997 to 05-02-2015). The results of Augmented Dickey-Fuller test for which lag length is chosen on the
Schwarz Information Criterion (SIC) and it is applied with intercept and trend. All the returns series were found to be stationary at its level and they are significant at 1 percent level. These results are also confirmed with Sahu, D. (2012) [4], Girish, G.P. (2012) [14] and Gahlot, R., Datta,K. and Kapil, S.(2010) [3]. The results of ARCH-LM test shows the F statistics value $F(5,4344)$ is 63.9516 which is highly significant. The R-square value is 0.0686 and adjusted $\mathrm{R}$-squared value is 0.0675 . Thus the null hypothesis is rejected and we can conclude that there are sufficient $\mathrm{ARCH}$ effects (Pati, P.C. and Rajib, P (2010) [10]. Table II depicts AR (1) - GARCH $(1,1)$ model for the pre-derivatives period (from 1-1-1997 to 4-6-2001). The results reveal that constant, $\mathrm{ARCH}$ (1) lagged residual returns coefficient $\alpha_{1}$ and GARCH (1) (lagged Nifty returns) and Nifty Junior returns are highly significant in the model.

Table III reveals AR $(1)$ - GARCH $(1,1)$ estimates for post derivatives period (5-6-2001 to 3-2-2015). The results depicts that the coefficient of futures dummy is -0.0518 which is highly significant at 1 percent level significance and coefficient of options dummy is -0.5469 which is highly significant have inverse relationship with Nifty returns.

$$
\begin{gathered}
\text { GARCH }=a_{0+} a_{1} \times \varepsilon^{2} t-1+\beta \times\left(R_{t-1}\right) \times R_{t-2, \text { Nifty Junior }+} \\
\delta_{2 \times} R_{t-2, S \& P 500}+\gamma \times D_{f}+\lambda \times D_{o} \\
\text { NIFTYRETURNS }=0.1308+[\text { AR }(1)=0.1161]
\end{gathered}
$$




$$
\begin{aligned}
& G A R C H=1.0561+0.2315 \times \varepsilon_{t-1}^{2}+0.5848 \times R_{t-1}-0.1020 \times \\
& R_{t-2 \text { Niffy Junior }}-0.2926 \times R_{t-2, \text { S\&P500 }}-0.0518 \times D_{f}-0.5469 \times D_{o}
\end{aligned}
$$

This clearly shows that after introduction of derivatives volatility of spot or cash market has reduced. These results are similar to those of Sahu, D.(2012) [4], Singla, R. (2012) [5], Sakhtivel, P. and Kamaiah, B.(2011) [7], Singh, G. and Kansal, S. (2010) [8], Pati, P.C. and Rajib, P.(2010) [10] and Gupta, K. and Singh, B.(2009) [11]. The contribution of $\beta_{1}$ (GARCH (1)) coefficient is highest 0.5848 in the model. This shows that news at t-1 day has a major impact on prices of Nifty on ' $t$ ' day. Figure1shows forecasted volatility of AR (1)-GARCH $(1,1)$ model predicted by equation.

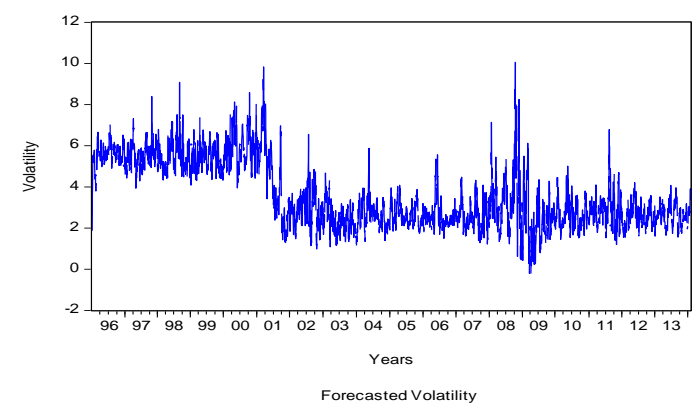

Fig. 1. Forecasted volatility of AR (1)-GARCH $(1,1)$ model predicted by equation.

\section{B. Investor's Perception about Indian Derivatives Market}

The second part of the analysis is to study about investment pattern of Indian investor, factors influencing derivative awareness level, perception about future of derivatives market in India. The data was collected for 522 respondents on their perception about Indian derivatives market. Figure II shows proportion of investment in various instruments by an average investor in India. Table IV shows ranking of various derivative instruments in India based on popularity.

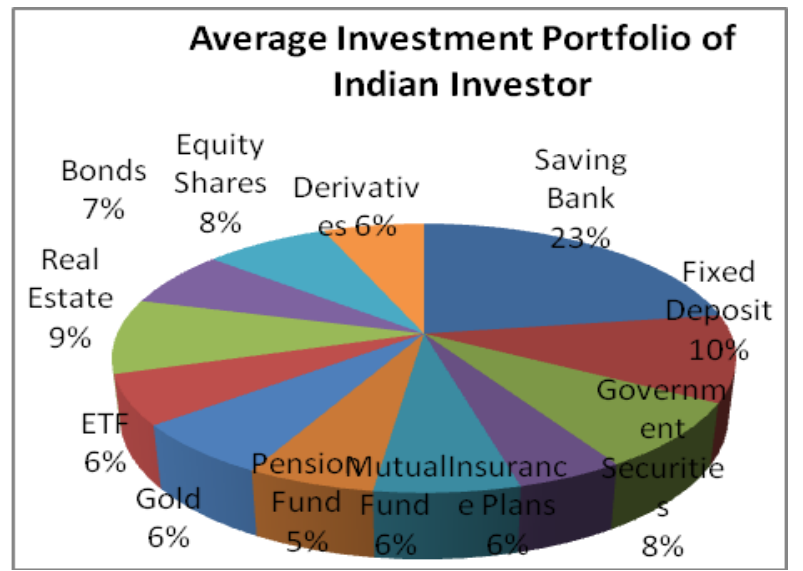

Fig. 2. Proportion of investment in various instruments by an average investor in India.

ANOVA testing was carried out to identify differences between investment patterns of males and females. The investment pattern in equity shows no difference for males and females as it has $\mathrm{F}$ value of 0.031 with 0.861 level of significance, which is not significant. The investment pattern in saving bankaccount, government securities, pension funds, mutual fund, ETFs and derivative investments is also not significantly different for males and females. The investment pattern of males and females was significantly different for fixed deposit. Significant difference is found in investment of males and females for Gold assets as ANOVA results are

TABLE IV : INVESTMENT IN DERIVATIVES INSTRUMENTS

\begin{tabular}{|l|c|c|c|} 
Derivatives Instrument & Frequency & Percent & Rank \\
\hline Stock Futures & 416 & 80.00 & 1 \\
\hline Forward Contracts & 46 & 8.85 & 6 \\
\hline Swaps & 31 & 5.96 & 9 \\
\hline Index Futures & 43 & 8.27 & 7 \\
\hline Stock Options & 200 & 38.46 & 2 \\
\hline Index Options & 54 & 10.38 & 5 \\
\hline Currency Derivatives & 74 & 14.23 & 4 \\
\hline Interest rate futures & 34 & 6.54 & 8 \\
\hline Commodity derivatives & 124 & 23.85 & 3 \\
\hline
\end{tabular}

Highly significant $(\mathrm{F}=3.931)$. Again significant difference is seen in the investment of bonds/debentures by males and females with $F$ value of 7.07 which is highly significant.

The respondents were further asked twenty five statements about the basics of derivatives and trading and this scale was termed as Derivatives Awareness Level (DAL). The results of multiple regression found seven independent variables constituted the optimum regression model.The evaluated regression model is highly significant the $\mathrm{F}$ rate 8.913 at 0 percent level significance. But the degree of explanation of the model is not very high as the adjusted $\mathrm{R}^{2}$ is only 14.8 percent. Auto correlation of residuals is tested with the use of Durbin Watson test. Because of the calculated value of 1.876 and the table of critical values it appears that in the evaluated model there is no problem in auto correlation of residuals.

$\mathrm{DAL}=52.114-4.968$ (Gender) +1.586 (Nature of employment) - 7.141 (workplace activity) + 2.554 (Education) +5.019 (Experience in derivation trading) + 7.157 (Awareness of financial market) + 3.106 (Return expectation).

TABLE V: CONSTRUCT OF FUTURE OF DERIVATIVES MARKET BY STRUCTURAL EQUATION MODELLING

\begin{tabular}{|l|l|}
\hline $\begin{array}{l}\text { Consolidation of exchanges is required to enjoy the } \\
\text { economies of scale }\end{array}$ & 0.107 \\
\hline $\begin{array}{l}\text { To improve derivative market awareness, stock exchange } \\
\text { or regulators should conduct investor training and } \\
\text { awareness programmes. }\end{array}$ & 0.236 \\
\hline $\begin{array}{l}\text { The Derivatives Exchange/Segment should have investor } \\
\text { grievances redressal mechanism which could be } \\
\text { approachable by every individual investor during trading } \\
\text { hours. }\end{array}$ & 0.444 \\
\hline $\begin{array}{l}\text { Regulators should take steps to increase investment in } \\
\text { Indian derivatives market. }\end{array}$ & 0.326 \\
\hline $\begin{array}{l}\text { With global integration of markets derivatives market is } \\
\text { going to increase }\end{array}$ & 0.234 \\
\hline $\begin{array}{l}\text { In future, growth of the economy will depend on the } \\
\text { growth of derivatives market. }\end{array}$ & 0.175 \\
\hline
\end{tabular}

Table V shows results of SEM on statements related to perception of investors about future of derivatives market in India. The table shows factor loading of significant statements of the model. ANOVA testing was carried out for identifying differences in perception about future of 
derivatives market in India. Age wise, nature of employment and annual family income were found to be significantly affecting perception of investors.

Rest all variables including gender, workplace activity, work experience, educational background and derivatives awareness level have non-significant difference about perception on future of derivatives market in India.

\section{CONCLUSION}

The study suggests that after the introduction of derivatives in the Indian financial markets, volatility of spot market has reduced. The final AR (1)-GARCH $(1,1)$ model show that overall volatility has reduced in the spot market after the introduction of derivatives. In the model all variables are highly significant. The above analysis shows that overall derivatives market has been able to achieve the purpose for which it was established. It has been able to reduce the volatility of the stock market over a period of more than a decade of its establishment.

The investment pattern in saving bank account government securities, pension funds, mutual fund, ETFs and derivative investments is also not significantly different for males and females. Awareness about financial markets, experience in derivatives trading, workplace activity and return expectation are significantly associated with derivative awareness level (DAL) of respondents. Gender, nature of employment and educational background also are significantly associated with derivatives awareness level of investor at 10 percent level of significance. Perception of investors about future of derivatives market in India include having an investor grievance redressal mechanism which is approachable under trading hours, steps to be taken by regulators to increase investments, conducting investor training and awareness programmes, global integration will happen, derivatives market will affect growth of the economy and consolidation of exchanges is required.

\section{REFERENCES}

[1] A. Antoniou, P. Holmes, and R. Priestley, "The effects of stock index futures trading on stock index volatility: An analysis of the asymmetric response of volatility to news?" The Journal of Futures Markets, vol. 18 , no. 2 , pp. $151-166,1998$.

[2] F. G. Kalantzis and N. T. Milonas, "Analyzing the impact of futures trading on spot price volatility: Evidence from the spot electricity market in France and Germany," Energy Economics, vol. 36, pp 454-463, 2013.

[3] R. Gahlot and S. K. Dutta, "Impact of futures trading on stock market: A study of BRIC countries," Study in Economies and Finance, Emerald Group, vol. 29, pp. 118-132, 2012.

[4] D. Sahu, "Effect of equity derivatives trading on spot market volatility in india-An empirical exploration," European Journal of Business and Management, vol. 4, no. 11, 2012.

[5] R. Singla, "Effects of derivatives on the volatility in the Indian stock market," Abhinav Journal, National Monthly Journal of Research in Commerce and Management, vol. 1, issue 4, pp. 78-82, 2012.

[6] G. Kaur, "Impact of derivatives trading on market volatility and liquidity," International Journal of Research in Commerce and Management, vol. 2, issue 3, no. 1, 2011.

[7] P. Sakhtivel and B. Kamaiah, "The effect of derivative trading on volatility of underlying stocks: Evidence from the NSE," Indian Journal of Economics and Business, vol. 10, issue 4, 2011.

[8] G. Singh and S. Kansal, "Impact of derivatives trading on stock market volatility during pre and post F\&O period: A case study of NSE," vol. 1 , no. $1,2010$.
[9] G. Saravanan and M. Deo, "Impact of futures and options trading on the underlying spot market volatility in India," International Review of Applied Financial Issues and Economics, vol. 2, issue 1, pp. 213.

[10] P. C. Pati, and P. Rajib, "Volatility and trading volume in an emerging futures market," Journal of Risk and Finance, vol. 11, no. 3, pp. 296-309, 2010

[11] K. Gupta and B. Singh, "Estimating the optimal Hedge ratio in the Indian equity futures markets," The IUP Journal of Financial Risk Management, vol. 6, pp. 39-48, 2009

[12] Kabir and Ikram, "Role of financial derivatives and its impact on indian capital market: A case study of national stock exchange (NSE) since 2000," South Asian Journal of Marketing and Management Research, vol, 2, no. 4, 2012

[13] S. A. M. Al-Rjoub and H. Azzam, "Financial crises, stock returns and volatility in an emerging stock market," Journal of Economic Studies vol. 39, no. 2, pp. 178-211, 2012.

[14] G. P. Girish, "GARCH model to study the effect of introduction of derivative trading on stock market volatility of National Stock Exchange (NSE) India," JM International Journal of Finance Research, vol. 2, issue 3, 2012.

[15] G. R. Datta, K. Saroj, and K. Sheeba, "Impact of derivative trading on stock market volatility in India: A study of S\&PCNX Nifty," Eurasian Journal of Business and Economics, vol. 3, no. 6, pp. 139-149, 2010.

[16] T. Mallikarjunappa and E. M. Afsal, "Impact of derivatives trading on stock market volatility: A study of nifty index," $A A M J A F$, vol. 4 , no. 2 , pp. 43-65, 2008.

[17] D. S. Swaroop and M. Bishnupriya, "Stock-exchange econometric models futures and spot market," Institute of Management Technology, vol. 12 , no. 2,2008

[18] S. W. Yu, "Index futures trading and spot price volatility," Applied Economics Letters, vol. 8, no. 3, pp. 183-186, 2001.

[19] D. Butterworth, "The impact of futures trading on underlying stock index volatility: The case of the FTSE mid 250 contract," Working Paper, Department of Economics, University of Durham, 1998.

[20] O. Priyanka, "Impact of derivatives expiration on underlying securities: Empirical evidence from India," MIBES, 2011.

[21] G. S. Hiremath, "Effects of option introduction on price and volatility of underlying assets - A Review," GITAM Review of International Business, vol. 1, no. 2, pp. 100-121, 2009.

[22] M. Gulen and M. Stewart, "Stock index futures trading and volatility in international equity markets," The Journal of Futures Markets, vol. 20 , no. 7, pp. 661-685, 2000.

[23] S. Figlewski, "Futures trading and volatility in the GNMA market," Journal of Finance, vol. 36, pp. 445-84, 1981.

[24] A. Chatrath, S. Ramchander, and F. Song, "Does options trading lead to greater cash market volatility?" Journal of Futures Markets, vol. 15, no. 7, pp. 785-803, 1995.

[25] L. H. Harris, "The October 1987 S\&P 500 stock-futures basis," Journal of Finance, vol. 44, pp. 77-99, 1989.

[26] S. A. Ross, "Information and volatility: The no-arbitrage martingale approach to timing and resolution irrelevancy," Journal of Finance, vol. 44, pp. 1-17, 1989.

[27] J. Narasimhan and A. Subrahmanyam, "Liquidity effects of the introduction of the S\&P 500 index futures contracts on the underlying stocks," Journal of Business, vol. 66, pp. 171-187, 1993.

[28] H. Al-Zoubi and B. K. Al-Zu'bi, "Market efficiency, time - varying volatility and the asymmetric effect in Amman stock exchange," Managerial Finance, vol. 33, pp. 490-499, 2007.

[29] K. Ray and A. K. Panda, "The impact of derivatives trading on spot market volatility: Evidence from indian derivatives market," Interdisciplinary Journal of Research in Business, vol. 1, no. 7, pp. 117-131, 2011

[30] R. Ananth, "Analysis and volatility persistence in middle east emerging equity markets," Emerald Studies of Economies and Finance, 2008.

[31] S. Angelos and L. Katerina, The Effects of Derivatives Trading On Stock Market Volatility: The Case of the Athens Stock Exchange, 2007.

[32] E. Katsikas, "Volatility and autocorrelation in European futures markets," Managerial Finance, vol. 33, pp.236-240, 2007.

[33] K. Saatcioglu and L. T. Starks, "The stock price - Volume relationship in emerging stock markets: The case of Latin America," International Journal of forecasting, vol. 14, pp. 215-225, 1998.

[34] S. Q. Xie and J. J. Huang, "The impact of index futures on spot market volatility in China," Emerging Markets Finance and Trade, vol. 50, pp 167-177, 2014.

[35] I. Stulec, T. Bakovic, and I. Duzevic, "The impact of company characteristics on derivatives usage: survey study of Large Croatian companies," Mediterranean Journal of Social Sciences, vol. 4, 2013. 
[36] B. R. Kumari and P. S. M. Shamira.,"A study of investor behavior on investment avenues in mumbai Fenil," Trans Asian Journal of Marketing \& Management Research, vol. 1, 2012.

[37] T. C. Thomas and G. Rajendran, "BB\&K Five-way model and investment behavior of individual investors: Evidence from India," Int. Journal of Economics and Management, pp. 115-127, 2012.

[38] R. T. Kumar, K. N. Balaji, and K. Prabu, An Empirical Study on Traders Perception on Options Trading with Special Reference to the Products in the National Stock Exchange, 2011.

[39] A. M. Martin, W. Rojas, J. L. Erausquin, and E. Vera, "Derivatives usage by non-financial firms in emerging markets: The peruvian case," Journal of Economics, Finance and Administrative Science, pp. 74-86, 2009.

[40] W. Guay and S. P. Kothari, "How much do firms hedge with derivatives?" Journal of Financial Economics, vol. 70, pp. 423-461, 2003.

[41] Investor.

[Online].

Available: http://www.anz.com/documents/au/investor/20F231203CoSecret.pdf

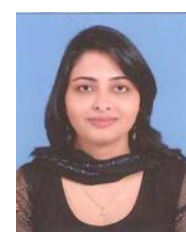

Divya Verma Gakhar is working as an assistant professor at the University School of Management Studies, Guru Gobind Singh Indraprastha University, Delhi. Prior to joining this institution she worked as a lecturer in the Department of Management, Kurukshetra University, Kurukshetra. She has completed her doctoral research project on the subject "Web-based Corporate Reporting Practices in India" from Guru Jamheshwar University of Science \& Technology, Hisar. She has a bright academic record and have won University scholarships during her graduation and post-graduation studies. She has also qualified doeacc A Level computer course. Her areas of academic interest include accounting and finance, financial derivatives, behavioural finance, economics, e-commerce. She has authored and edited four books namely micro and macro economics, web-based corporate reporting practices in India, Contemporary Issues in Corporate Finance and Emerging Issues in Indian Financial Markets. She has submitted UGC Major Research Project titled "Financial Derivatives Market in India: Present Status and Future Prospects". She has published 18 papers in national and international journals and have presented papers in number of seminars and conferences. 